\title{
Study on the Form of Electricity Theft in Area X
}

\author{
Hardianto ${ }^{1, *)}$, Akbar $^{2}$ \\ Sekolah Tinggi Teknologi Bontang, Bontang, Indonesia \\ hard_yan@yahoo.com ${ }^{1}$, akbarliwang@gmail.com ${ }^{2}$ \\ ${ }^{*}$ Corresponding author
}

\author{
Keywords: \\ Behavior, Violations, \\ Electricity Theft, Prevention, \\ Customers
}

\begin{abstract}
The behavior of theft of electricity is a form of violation that harms many parties. This research aims to know the violation class and category of violations by electricity customers in 3 years. The research approach used was qualitative research. The data sources in this study involved 1 management party, customers in the $1^{\text {st }}$ year were 1,200 people, the $2^{\text {nd }}$ year were 1,200 people, and the $3^{\text {rd }}$ year were 700 people. Data collection techniques used were observation, documentation, literature study, and interviews. All data were analyzed inductively including data reduction, data presentation, and verification (arranging conclusion). The results of the research showed that the total number of violations for 3 years reached $7.1 \%$ which was distributed to $2.2 \%$ for class violations and $4.9 \%$ for categories of violations. The category of violations that occurred on the customer's side showed that it was greater than class violations. The number of class 3 violations reached $0.9 \%$ and violations of this class were higher than other classes. Meanwhile, the $k W h$ violation category reached $2.6 \%$ and this violation category was higher than other categories. Based on the rate of the number of violations each year, there was an increase in violations by $0.2 \%-0.9 \%$.
\end{abstract}

\section{INTRODUCTION}

Social life creates quite complex interactions between each individual in attitude and behavior. There are 3 perceptions of the relationship between the two, namely (1) influencing/sometimes not influencing, (2) both being bound by norms and (3) together with norms (Christiani, 2016). Attitude is an action or did that is influenced by the knowledge level of a person to create a belief. That belief is an evaluation to accept or reject. Meanwhile, according to Skiner, behavior is a person's response or reaction to the situations and conditions he experiences. Behavior can create an action that is detrimental or beneficial for both himself and others. Control over behavior that harms others or oneself in society is religious norms, legal norms, and other norms.

Legal norms function as a tool to regulate individuals in social life to create a sense of security and order. Concerning an institution, legal norms are manifested in the form of written regulations that are binding on each individual and this encourages the creation of a legal system. In Indonesia, there are 
two legal systems, namely criminal law and civil law. Criminal law aims to prevent or inhibit individual actions that are not following applicable law. Criminal Law has principles including those regulated in the Criminal Code (KUHP) (Atmadja, 2018).

Forms of law violations that lead to criminal law include theft. Theft behavior is regulated in the Criminal Code (KUHP) book II chapter XXII Articles 362 to 367. The categories of goods for acts of theft are tangible things including animals, money, clothes, necklaces, electric power, and gas. The act of stealing electricity as an unlawful act has been regulated in the Electricity Law Number 30 of 2009 as part of criminal behavior and at the same time as a crime category. Every individual/group/institution that commits theft of electricity is threatened with criminal threats and fined. Data theft of electricity in Indonesia is quite scattered, such as Balikpapan, East Kalimantan (William, 2020), West Sulawesi (Ismail, 2018), Riau, Kampar Regency (Vandiwinata, 2018), and Malang City, East Java (Arsenal, 2021). Meanwhile, on a global scale, electricity theft has increased in 102 countries from 1980 and 2000 (Smith, 2004).

Based on the distribution of data on electricity theft that occurred in Indonesia and globally, researchers will conduct an in-depth analysis of the forms of violations to electricity. Therefore, the initial study carried out was to conduct observations to further identify various electricity thefts that occurred based on the data. The object of observation in this research is the manager of electricity in area $\mathrm{X}$ and the customer as the sample. Observation results show that the total installed power is $55,154,990 \mathrm{VA}$ which is then distributed to $\mathrm{kWh}$ meters prepaid are 20,943 customers and the postpaid is 16.677 customers. This distribution can be used to identify the presence or absence of theft by users. Identification of the forms of theft by users is rarely done so that the mapping cannot be predicted.

It is known that data on electricity theft in Indonesia is spread across West Sulawesi, Riau, and East Java. Meanwhile, area X, which has electricity providers and customers, is not yet known about the level of electricity theft. Therefore, the study in this research includes: (1) the form of violations and categories of violations, (2) the number of violations each year, (3) whether or not there is an increase in violations every year, and (4) potential losses caused by violations. every year. Various variables used in the identification of electric current violations include the customer/consumer destroying the seal belonging to the limiting device or not following the original, changing the ability of the limiting device to be greater, among others by changing the relay setting of the limiting device and reversing the phase with neutral or other things. other things to affect the power limit. Meanwhile, the detection of electricity theft by customers has been done but is limited to reading the current consumption of the customer's electricity (Walukow, Doringin, \& Kunci, 2020), the daily consumption of the customer's electricity needs (Feng et al., 2020), and modeling the central transformer for inputs. and electrical power output (Fuada, 2016).

Legally, electricity theft violates the law and the types of violations only reach 6 items (Sutrisni, 2012). However, in the research, the types of violations used are divided into two aspects, namely (1) class violations and (2) categories of violations. Therefore, the aim of this research to be achieved is to describe the forms of violations that include (1) class violations, (2) categories of violations, and excess electricity cause of the violation.

\section{METHOD}

This research uses a descriptive qualitative research approach, where the researcher is the main key in the research because the researcher is the planner, implementer, data processor, and conclusion maker. This research is to describe the class violations and categories of violations committed by customers in the $1^{\text {st }}$ year, $2^{\text {nd }}$ year, and $3^{\text {rd }}$ year. Observations on class violations include class 1 , class 2 , class 3 , and class 4 violations. Meanwhile, the category of violations includes category 1, category 2, category 3 , 
and $\mathrm{kWh}$. The indicators used to identify the presence or absence of class violations and categories of violations can be observed in Table 1 and Table 2.

Table 1

Violations Class

\begin{tabular}{ll}
\hline Description & Indicator \\
\hline Class 1 & Affect power limit \\
Class 2 & Affect energy measurement \\
Class 3 & Affects power limits and energy measurements \\
Class 4 & Factors outside the customer \\
\hline
\end{tabular}

Table 2

Violations Criteria

\begin{tabular}{ll}
\hline Description & Indicator \\
\hline Criteria 1 & There are 7 factors \\
Criteria 2 & There are 2 factors \\
Criteria 3 & Natural factor \\
Criteria 4 & Transition factor \\
\hline
\end{tabular}

Data collection techniques used to obtain research data are interviews, observation, documentation, and literature study. The source of this research data consists of two parts, namely the first part comes from 1 management party and the second part comes from 3100 customers. The next selection of data sources as research subjects used simple random sampling. The number of research subjects for violations in each period is 1,200 customers in the $1^{\text {st }}$ year, 1,200 customers in the $2^{\text {nd }}$ year, and 700 customers in the $3^{\text {rd }}$ year. The entire research data was then analyzed inductively with three stages, namely data reduction, data exposure, verification, and conclusion taking.

\section{RESULTS AND DISCUSSION}

The study of violations of the existing electricity supply in area $X$ focuses on two rules, namely class violations (Decision of the Board of Directors of PLN Number 1486.K/DIR/2011 concerning Control of Electricity Use (P2TL)) and categories of violations (Decision of the Board of Directors of PLN Number 163-1KIDIR /2012 about Adjustment of Electricity Consumption Account). Class violations include:

a. Class violations I (P-I) are violations that affect the power limit. marked by the presence of:

1) The barrier seal is missing, damaged, or does not match with the original.

2) The limiting tools themselves are missing, damaged, or does not match with the original.

3) There is a change in the limiting tools, especially in the limiting relay setting, and reversing the phase with neutral which causes the limiter's ability to be greater.

4) Other factors have the purpose of influencing the power limit.

b. Class violations II (P-II) are violations that affect energy measurement. Marked by the presence of:

1) The Tera seal and/or PLN's seal on the measuring tools and/or its equipment is one or all of the missing/incomplete, damaged/broken, or does not match with the original.

2) The measuring tools and/or equipment are missing or do not match the original.

3) The Measuring tools and/or equipment are not functioning properly even though all PLN Seals and Tera Seals are in complete and good condition.

c. Class violations III (P-III) are violations that affect the power limit and affect energy measurements.

d. Class violations IV (P-IV) are violations committed by non-customers.

Meanwhile, for violations category include:

a. Category 1 is marked by the presence 7 of causative factors, namely: 
1) The multiplication factor of the meter of the local measuring instrument is not the same as the time factor written on the account.

2) The use of electricity to customers whose designation is not following the power and/or tariff class according to the power purchase agreement letter.

3) The correction factor on the billed account does not match the measurement connection system installed by the local customer.

4) The transformer usage factor in the customer master data does not match the locale.

5) The reading of the local $\mathrm{kWh}$ and $\mathrm{kVA}$ meter register numbers does not match the meter number on the account.

6) Mutation failure causes the account bill not to comply with the applicable provisions.

7) The time switch is not working properly.

b. Category 2 can occur because

1) The amount/all of the energy that has been used by the customer is not measurable and not recorded. 2 factors can affect this condition, namely the incompatibility of the wiring of the measuring tool and the measuring tool and equipment not functioning. As long as the seal does not change, the fault is not imposed on the customer as a violation

2) The amount of power that has been used by the customer is more than or less and The cause of this condition consists of the limiting device is not functioning and the limiting device installed is larger or smaller than it should be. As long as the limiting device is larger than it should be and the seal is not damaged then the fault is not imposed on the customer.

c. Category 3 may occur due to natural conditions such as broken Tera seals and APP equipment damaged due to corrosion.

d. $\mathrm{kWh}$ means a pure follow-up bill due to switching/updating manual $\mathrm{kWh}$ to digital.

The number of violations collected as data in the $1^{\text {st }}$ year, $2^{\text {nd }}$ year, $3^{\text {rd }}$ year according to class and category violations can be observed in Table 3 .

Table 3

Number of Violations During Observation

\begin{tabular}{ccccccccc}
\hline \multirow{2}{*}{ Year } & \multicolumn{4}{c}{ Class } & \multicolumn{4}{c}{ Category } \\
\cline { 2 - 9 } & P-I & P-II & P-III & P-IV & K-I & K-II & K-III & kWh \\
\hline $1^{\text {st }}$ & 8 & 2 & 24 & 5 & 0 & 0 & 0 & 0 \\
$2^{\text {nd }}$ & 5 & 5 & 2 & 0 & 0 & 8 & 0 & 67 \\
$3^{\text {rd }}$ & 4 & 5 & 1 & 7 & 0 & 63 & 0 & 13 \\
\hline
\end{tabular}

Violations in the $1^{\text {st }}$ year included violations of P-I, P-II, P-III, and P-IV. P-III violations were in the highest order, namely, there were as many as $2 \%$ of 1200 customers and Class 2 was in the lowest order, namely $0.2 \%$ of 1,200 customers. The causes of class violations tend to affect power limits and measurements that occur in customers. Meanwhile, the category of violations did not occur to users so that the biggest violation in this $2^{\text {nd }}$ year was class violations. Based on these conditions, the total number of violations that occurred in the $1^{\text {st }}$ year for class and category violations was $3.3 \%$.

Customers who committed class violations in the $2^{\text {nd }}$ year experienced a decrease in P-I, P-III, and PIV. The number of respondents involved in the $2^{\text {nd }}$ year was 1,200 customers. A quite drastic decrease in violations was P-III from $2 \%$ to $0.2 \%$ and without any violations was P-IV. Meanwhile, the P-II class showed an increase in violations from $0.2 \%$ to $0.4 \%$. The number of class violations in the $2^{\text {nd }}$ year reached $1 \%$. Meanwhile, for the $2^{\text {nd }}$ year category violations occurred in K-II and $\mathrm{kWh}$ with $0.7 \%$ and $5.6 \%$ achievements. The category of violations with a fairly high increase is the kWh category. Meanwhile, for K-I and K-III, 0\% was observed. Based on the violation category data, the total achievement is $6.3 \%$. Therefore, the total violations that occurred in the $2^{\text {nd }}$ year both from class violations and violation categories reached $7.3 \%$. 
Customers who commit class violations in the $3^{\text {rd }}$ year showed that the data is spread out for all Classes. From the existing class violations, P-III is quite minimal and P-IV is higher than other classes. The number of respondents in the $3^{\text {rd }}$ year involved 700 customers so that the percentage of achievements for violations of P-III and P-IV were $0.1 \%$ and $1 \%$. The total number of class violations in this $3^{\text {rd }}$ year reached $2.4 \%$. Meanwhile, the violation category showed an increase in K-II and a decrease in $\mathrm{kWh}$. The percentages between the two were $9 \%$ and $1.9 \%$. Thus, the total category of violations in the $3^{\text {rd }}$ year reached $10.9 \%$. Based on the $3^{\text {rd }}$ year data, the largest number of violations was in the category of violations, and the total number of violations, both class and category violations, reached $13.3 \%$.

With the violation of both class and category violations, the excess electrical energy released reached $832,113 \mathrm{kWh}$ for 3 years. Data excess energy in each year can be observed in Table 4.

Table 4

Number of Violations and Excess Energy

\begin{tabular}{cccc}
\hline Year & Class and Category & Percentage & Energy $(\mathbf{k W h})$ \\
\hline $1^{\text {st }}$ & 39 & 3.3 & 169,766 \\
$2^{\text {nd }}$ & 87 & 7.3 & 463,960 \\
$3^{\text {rd }}$ & 93 & 13.3 & 198,387 \\
\hline \multicolumn{4}{c}{} \\
\hline
\end{tabular}

Excess energy due to violations committed, the amount of energy released every year reaches 169,766 $\mathrm{kWh}-463,960 \mathrm{kWh}$. The biggest excess of energy occurred in the $2^{\text {nd }}$ year when compared with the $1^{\text {st }}$ year and $3^{\text {rd }}$ year. Based on data analysis that showed the trend of increasing violations and the use of excess electrical energy, it is recommended that electricity providers in area X can take preventive and persuasive efforts so that violations in the following years can be minimized/prevented. The form of prevention can be in the form of socialization, carrying out observations, patrols, collaboration with related agencies, and arrests to raise criminal cases (Novarizal \& Basyaruddin, 2019). This kind of theft of electricity is very detrimental to society, can cause environmental damage, and cause economic problems due to the increase in services that need to be provided (Briseño \& Rojas, 2020). In addition, several factors were found that encourage someone to behave in this way, namely corruption, population displacement, and poverty (Gaur \& Gupta, 2016). Other factors are low legal awareness, the presence of irresponsible persons, the factor of fines that must be paid by customers, installation deviations, and lack of socialization from electricity providers (Alfarabi, Thalib, \& Hambali, 2021).

\section{CONCLUSIONS}

The behavior of electricity theft by customers caused an increase in energy consumption which reaches $832,113 \mathrm{kWh}$ for 3 years. The number of violations that occurred in the 3 years observation data reached $7.1 \%$ or 219 customers. The violations were distributed in-class violations which reached $2.2 \%$ and categories of violations which reached $4.9 \%$. This means that the category of violations is higher than that of class violations. The difference between the two was $2.5 \%$. In class violations, Class 3 (P-III) which reached $0.9 \%$ ranks the highest compared to other classes. Meanwhile, the largest violation category was $\mathrm{kWh}$ which reached $2.6 \%$ compared to other violation categories. The categories of violations that did not occur to customers were the $\mathrm{K} 1$ and $\mathrm{K} 3$ categories. Overall (violations of class and category of customers) had a rate of an increasing number of violations every year which reached $0.2 \%-0.9 \%$.

\section{ACKNOWLEDGMENT}

The research team would like to thank the Head of the Bontang College of Technology and the Chair of the Institute for Research and Community Service (LPPM) of the Bontang College of Technology 
who have provided financial support for this research from the beginning to the preparation of reports and publishing the research results.

\section{REFERENCES}

Alfarabi, Thalib, \& Hambali. (2021). Aspek Kriminologis terhadap Kejahatan Pencurian Listrik di Wilayah Kota Makassar. Journal of Lex Generalis (JLS), 2(6), 1703-1715.

Arsenal, R. (2021). Upaya PT PLN dalam Menanggulangi Pencurian Aliran Tenaga Listrik di Kota Malang (Studi di PT PLN Persero Kota Malang). Universitas Muhammadiyah Malang.

Atmadja, D.G. (2018). Asas-Asas Hukum dalam Sistem Hukum. Kertha Wicaksana, 12(2), 145-155.

Briseño, H. \& Rojas, O. (2020). Factors Associated with Electricity Theft in Mexico. International Journal of Energy Economics and Policy, 10(3), 250-254. https://doi.org/10.32479/ijeep.9002

Christiani, W. (2016). Hukum sebagai Norma Sosial Memiliki Sifat Mewajibkan. Neliti, 4(1), 151167.

Feng, X., Hui, H., Liang, Z., Guo, W., Que, H., Feng, H., Yao, Y., Ye, C., \& Ding, Y. (2020). A Novel Electricity Theft Detection Scheme Based on Text Convolutional Neural Networks. Energies, 13(21), 1-17. https://doi.org/10.3390/en13215758

Fuada, S. (2016). Proposed An Intelligent System for Electricity Theft Detector at Smart City Scenarios. International Journal of Applied Power Engineering (IJAPE), 5(1), 51. https://doi.org/10.11591/ijape.v5.i1.pp51-58

Gaur, V. \& Gupta, E. (2016). The Determinants of Electricity Theft: An Empirical Analysis of Indian States. Energy Policy, 93, 127-136. https://doi.org/10.1016/j.enpol.2016.02.048

Ismail, S. (2018). Tinjauan Kriminologis - Yuridis terhadap Tindak Pidana Pencurian Aliran Listrik (Studi Kasus di PLN Wilayah Sulselbar). University of Muhammadiyah Malang.

Novarizal, R. \& Basyaruddin, B. (2019). Upaya PLN dalam Mengatasi Pencurian Aliran Listrik (Studi Kasus di Kecamatan Siak Hulu Kabupaten Kampar). Sisi Lain Realita, 3(2), 60-74. https://doi.org/10.25299/sisilainrealita.2018.vol3(2).3719

Smith, T.B. (2004). Electricity Theft: A Comparative Analysis. Energy Policy, 32(18), 2067-2076. https://doi.org/10.1016/S0301-4215(03)00182-4

Sutrisni. (2012). Tinjauan Yuridis tentang Pencurian Aliran Listrik. Seminar Nasional Membangun Strategi Pertumbuhan Regional Berkualitad Dalam Ketidakseimbangan Global, 99-105.

Vandiwinata, Y. (2018). Penyelesaian Tindak Pidana Pencurian Aliran Listrik di Luar Pengadilan Berdasarkan Undang-Undang Nomor 30 Tahun 2009 tentang Ketenagalistrikan di Wilayah Hukum Tapung Kabupaten Kampar. JOM Fakultas Hukum, 5(2), 1-15.

Walukow, S., Doringin, F., \& Kunci, K. (2020). Sistem Pendeteksi dan Penginformasi Terjadinya Pencurian Listrik Berbasis SMS Gateway dan Arduino. The 11th Industrial Research Workshop and National Seminar Bandung, 26-27.

William, D. (2020). Legal Accountability the Suspect Theft of Electricity in the City of Balikpapan. Lex Suprema (Jurnal Hukum Fakultas Hukum Universitas Balikpapan), 2(1), 219-239. 